\title{
갑상선기능항진과 갑상선눈병증의 첫 증상으로서 후천사시와
Acquired Strabismus and Diplopia as Initial Presentation Signs of Hyperthyroidism and Thyroid Eye Disease
}

\author{
정승민 ${ }^{1} \cdot$ 김원제 $^{2}$ \\ Seung Min Chung, MD ${ }^{1}$, Won Jae Kim, MD $^{2}$ \\ 영남대학교 의과대학 내과학교실 ${ }^{1}$, 영남대학교 의과대학 안과학교실 ${ }^{2}$ \\ Department of Internal Medicine, Yeungnam University College of Medicine ${ }^{I}$, Daegu, Korea \\ Department of Ophthalmology, Yeungnam University College of Medicine ${ }^{2}$, Daegu, Korea
}

\begin{abstract}
Purpose: We evaluated the clinical characteristics of patients who recently acquired strabismus and diplopia as the initial presentations of hyperthyroidism and thyroid eye disease (TED).

Methods: The medical records of patients with acquired strabismus and diplopia who visited our clinic for evaluation between January 2017 and December 2018 were retrospectively reviewed; patients diagnosed initially with hyperthyroidism and TED were included in this study.

Results: A total of 410 patients were referred to our clinic for the evaluation and treatment of diplopia. Among these patients, 12 $(2.9 \%, 12 / 410)$ showed acquired strabismus and diplopia as the initial presentation signs of hyperthyroidism and TED. The mean age of onset of diplopia was 54.7 years (range, $18-78$ years). Nine patients (75\%, 9/12) were male. Six male patients were active smokers at the initial presentation. Hypotropia was the most common type of strabismus $(83.3 \%, 10 / 12)$. The mean angle of hypodeviation was 17.5 prism diopters (PD) (range, 4-40 PD). One patient showed exotropia with hypotropia and one patient showed esotropia with a bilateral up gaze limitation. Four male patients (all active smokers) underwent strabismus surgery, and one female patient underwent orbital decompression surgery.

Conclusions: The incidence of acquired strabismus and diplopia as the initial presentation sign of hyperthyroidism was predominant in male patients. Hypotropia was the most common type of strabismus. Male patients who smoked were more likely to show progression to a severe clinical course than female patients.
\end{abstract}

J Korean Ophthalmol Soc 2020;61(3):288-293

Keywords: Diplopia, Hyperthyrodism, Thyroid-associated ophthalmopathy

두눈복시는 두 눈의 눈운동장애로 인하여 발생한다. ${ }^{1}$ 눈 운동장애는 눈확(orbit), 외안근, 신경근이음부(neuromuscular

- Received: 2019. 6. 20.

- Revised: 2019. 9. 10.

- Accepted: 2020. 2. 21.

- Address reprint requests to Won Jae Kim, MD Department of Ophthalmology, Yeungnam University Hospital, \#170 Hyeonchung-ro, Nam-gu, Daegu 42415, Korea

Tel: 82-53-620-4191, Fax: 82-53-626-5936

E-mail: eyekwj@ynu.ac.kr

* Conflicts of Interest: The authors have no conflicts to disclose. junction) 또는 눈운동신경을 포함하는 뇌 병변에 의해서 발 생할 수 있다. 갑상선눈병증(thyroid eye disease)은 성인에 서 후천사시와 이로 인한 두눈복시의 가장 흔한 원인 중 하 나이다. ${ }^{1-4}$ 갑상선눈병증은 자가면역질환으로 눈확과 눈확 주위 조직에 영향을 미쳐 눈꺼풀뒤당김(lid retraction), 안구 돌출(proptosis), 시력저하, 사시 등을 유발할 수 있다.,3 갑 상선눈병증의 진단은 이전에 갑상선기능이상을 진단받은 환자에서 이루어지는 경우가 많다. 하지만, 후천사시와 복 시가 갑상선눈병증의 첫 눈 증상일 수 있고, 이를 통해 전 신적으로 갑상선기능항진이 진단될 수 있다. ${ }^{5}$ 이에 본 연구 
에서는 후천사시와 복시로 내원하여 갑상선눈병증과 갑상 선기능항진을 진단받은 환자들의 임상양상을 분석하여, 후 천사시와 복시 환자의 진료에 도움을 주고자 한다.

\section{대상과 방법}

본 연구는 영남대학교병원 임상연구심의위원회(Institutional Review Board, IRB)의 승인을 받아 진행하였으며 헬싱 키선언(Declaration of Helsinki)을 준수하였다(승인 번호: 2018-09-013-001). 2017년 1월부터 2018년 12월까지 후천 사시와 복시로 내원한 환자들의 의무기록을 후향적으로 분 석하였다. 이들 중 복시의 원인감별을 위해 시행한 검사에 서 갑상선눈병증과 갑상선기능항진을 처음 진단받은 환자 들이 연구에 포함되었다. 이전에 갑상선기능이상을 진단받 은 적이 있거나 정상갑상선기능(euthyrodism) 갑상선눈병 증환자는 연구에서 제외하였다.

내원한 환자들에게 병력 청취를 하였으며, 시력검사와 눈꺼풀검사, 동공반응검사, 안구운동검사, 세극등현미경검 사, 안압검사 그리고 안저검사를 포함한 안과검사를 시행 하였다. 사시각검사는 원거리 $(6 \mathrm{~m})$ 와 근거리 $(33 \mathrm{~cm})$ 에서 교대프리즘가림검사를 시행하여 시행하였으며, 운동제한 소견도 확인하였다. 눈검사에서 예측되는 복시의 원인에 따라서 뇌자기공명영상(magnetic resonance imaging, MRI) 또는 눈확 전산화단층촬영술(computed tomography, CT)을 시행하였다. 갑상선기능검사(thyroid function test)와 항아 세틸콜린수용체항체(anti-acetylcholine receptor antibody)를
포함하는 혈액검사를 시행하였다. 갑상선기능검사는 thyroid stimulating hormone (TSH), free tri-iodothyronine (T3), 그 리고 thyroxine (T4)을 시행하였다. 갑상선기능검사에서 이 상 결과를 보인 경우 갑상선기능이상에 대한 추가 평가와 치료를 위해서 내분비내과로 환자를 의뢰하였다. 눈 임상 소견, 갑상선기능검사 결과, 영상검사에서 외안근 비대의 확인을 통하여 갑상선눈병증을 진단하였다. 갑상선눈병증 의 활성도(activity)는 clinical activity score (CAS)를 통하 여 확인하였다. ${ }^{6}$ 사시수술은 적어도 6 개월 정도 안구운동 소견의 안정화를 확인하고 난 뒤 시행하였다. 안와감압술 (orbital decompression)은 압박시신경병증(compressive optic neuropathy) 환자에서 고농도 스테로이드 치료가 효과 가 없을 때 시행하였다.

\section{결 과}

연구기간 동안 총 410 명의 환자가 후천사시와 복시로 안 과에 의뢰되었다. 총 12 명 $(2.9 \%, 12 / 410)$ 이 갑상선눈병증과 갑상선기능항진으로 처음 진단받았고, 이들 중 9명이 남성 이었다 $(75 \%, 9 / 12)$. 대상 환자들의 기본 임상정보는 Table 1 과 같았다. 복시가 발생한 평균 나이는 54.7세였다(범위, 18-78세). 복시 발생 이후 평균 3.9개월에 안과에 내원하였 다(범위, 0.5-12개월). 6명의 남성은 첫 내원 시 흡연자였다 (환자 $1,3,5,9,10,11$ ).

안구운동장애의 형태로는 하사시가 가장 많았다 $(83.3 \%$, $10 / 12$ ). 평균 하사시각은 17.5 프리즘디옵터(prism diopters,

Table 1. Clinical characteristics of patients who have acquired strabismus and diplopia as the initial presentation signs of hyperthyroidism and thyroid eye disease

\begin{tabular}{|c|c|c|c|c|}
\hline \multirow[b]{2}{*}{ Patient (sex/age [years]) } & \multirow[b]{2}{*}{$\begin{array}{l}\text { Duration of diplopia } \\
\text { (months) }\end{array}$} & \multicolumn{3}{|c|}{ Findings at the initial visit } \\
\hline & & $\begin{array}{l}\text { Ocular deviation at distance } \\
\text { fixation (PD) }\end{array}$ & Lid retraction or proptosis & $\begin{array}{l}\text { Enlargement of extraocular } \\
\text { muscles on imaging study }\end{array}$ \\
\hline $1(\mathrm{M} / 66)$ & 0.5 & HoT 12 & Lid retraction \& Proptosis & Yes \\
\hline $2(\mathrm{M} / 18)$ & 2 & HoT $25 \&$ XT 30 & No & No \\
\hline $3(\mathrm{M} / 55)$ & 1 & HoT 4 & Lid retraction \& proptosis & Yes \\
\hline $4(\mathrm{M} / 53)$ & 0.5 & HoT 10 & Lid retraction \& proptosis & Yes \\
\hline $5(\mathrm{M} / 47)$ & 3 & HoT $16 \&$ XT 4 & Proptosis & Yes \\
\hline $6(\mathrm{~F} / 67)$ & 1 & HoT 16 & Lid retraction \& proptosis & Yes \\
\hline $7(\mathrm{~F} / 32)$ & 1 & HoT $30 \&$ XT 4 & Lid retraction & Yes \\
\hline $8(\mathrm{~F} / 76)$ & 10 & HoT 40 & Lid retraction & Yes \\
\hline $9(\mathrm{M} / 59)$ & 2 & $\begin{array}{c}\text { ET } 40 \text { \& } \\
\text { Right HoT } 40 \text { \& Left HoT } 30\end{array}$ & No & Yes \\
\hline $10(\mathrm{M} / 62)$ & 12 & HoT 25 & Lid retraction & Yes \\
\hline $11(\mathrm{M} / 43)$ & 1 & HoT $16 \&$ ET 4 & Lid retraction & Yes \\
\hline $12(\mathrm{M} / 78)$ & 1 & HoT 6 & Lid retraction & No \\
\hline
\end{tabular}

$\mathrm{PD}=$ prism diopters $\mathrm{M}=$ male HoT = hypotropia $\mathrm{XT}=$ exotropia $\mathrm{F}=$ female ET = esotropia. 
$\mathrm{PD)}$ 였다(범위, 4-40PD). 1명은 외사시와 하사시를 보였고 (환자 2$){ }^{5} 1$ 명은 내사시와 양안 상측 운동제한을 보였다(환 자 9). MRI 또는 CT 영상검사에서 외안근비대 소견을 10 명 에서 확인할 수 있었다. 1명이 혈청 항아세틸콜린수용체항체 양성을 보였다(환자 8). 평균 $\mathrm{CAS}$ 는 2.1이었다(범위, 1-4). 경과 관찰 중 4 명의 남성이 사시수술을 시행 받았으며(환자 $3,5,9,10), 1$ 명의 여성이 안와감압술을 시행받았다(환자 6).

\section{증례 1 (환자 5)}

47세 남자가 3 개월 동안 지속된 수직복시로 왔다. 복시 는 처음에는 간헐적이었으나 점차 심해져 이제는 항상 있 다고 했다. 증상은 일중변화(diurnal variations)를 동반하지 않았다. 이전에 당뇨, 고혈압, 종양, 자가면역질환 등의 전 신 질환 또는 안과 질환의 과거력은 없었다. 두통, 눈뒤통 증, 귀울림(tinnitus) 등의 다른 신경학적 증상을 동반하지 않았다. 교정시력은 양안 20/20이었다. 동공반응검사에서 상대구심동공운동장애는 없었다. 우안의 안구돌출을 보였 으나, 양안의 눈꺼풀 이상 소견은 없었다. 안구운동검사에 서 정면 주시에서 우안의 $16 \mathrm{PD}$ 하시시와 $4 \mathrm{PD}$ 외사시를 보 였고, 우안 상측 운동제한이 있었다(Fig. 1A). 뇌 MRI에서
우안 아래곧은근(inferior rectus muscle)의 비대를 확인하였 다(Fig. 1B). 갑상선기능검사에서 $\mathrm{TSH}$ 는 $0.01 \mathrm{mIU} / \mathrm{L}$ (정상 범 위, 0.3-4 mIU/L)로 저하되어 있었고, free T4는 $23.75 \mathrm{pmol} / \mathrm{L}$ (정상 범위, $10-25 \mathrm{pmol} / \mathrm{L}$ ), total $\mathrm{T} 3$ 는 $2.58 \mathrm{nmol} / \mathrm{L}$ (정상 범위, 0.3-4 nmol/L)였다. Thyroid receptor antibody (TRAb) 는 $3.85 \mathrm{U} / \mathrm{L}$ (정상 범위, 0-1.5 U/L), thyroid peroxidase (TPOAb)와 anti-thyroglobulin antibodies는 음성이었다. 갑상 선초음파검사에서 균질한(homogeneous), 동일에코(isoechoic) 의 비갑상선종을 확인하였고, 정상 도플러혈류(Doppler flow) 를 보였다. Tc-99 m 갑상선스캔에서 양측엽에 약간 불규칙 적인 섭취를 보였다. 환자는 무증상 갑상선기능항진을 진 단을 받았으며, 저용량 methimazole $(2.5-5.0 \mathrm{mg})$ 치료를 시작하였다. 복시 증상 호전을 위해서 프리즘안경을 처방 하였다. 12 개월의 경과 관찰기간 동안, 정면주시에서 우안 하사시는 $40 \mathrm{PD}$ 로 증가하였다. 사시수술로 우안의 아래곧 은근 $5 \mathrm{~mm}$ 후전술과 좌안의 위곧은근 $7 \mathrm{~mm}$ 후전술을 시 행하였고, 환자는 수술 후 복시의 호전을 보였다.

\section{증례 2 (환자 9)}

60세 남자가 2달 전에 발생한 수직복시로 내원하였다.
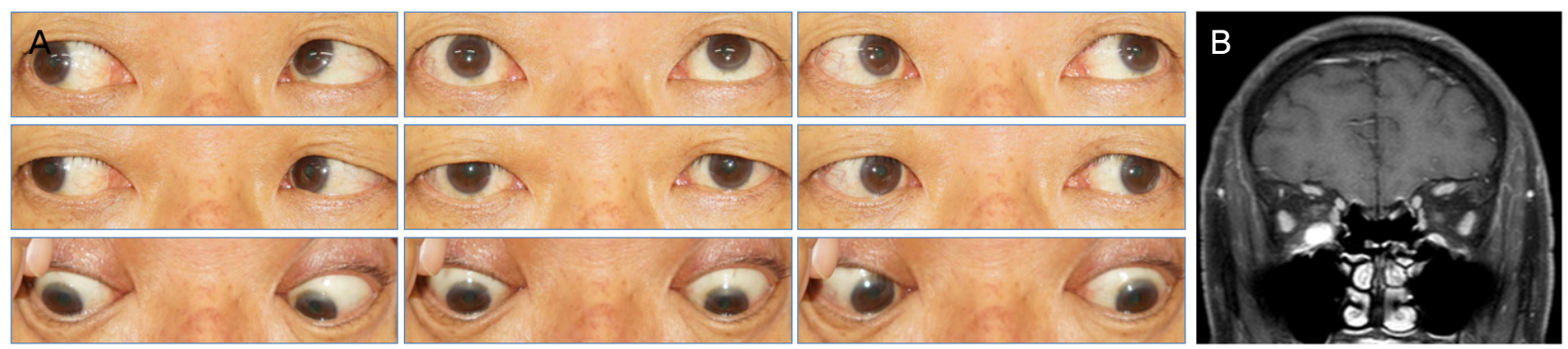

Figure 1. Patient 5 with nine diagnostic position at the initial presentation. (A) Patient demonstrated hypotropia in the right eye in the primary position with up gaze limitation. (B) Magnetic resonance imaging of the brain showed enlargement of the inferior rectus muscle in right eye.
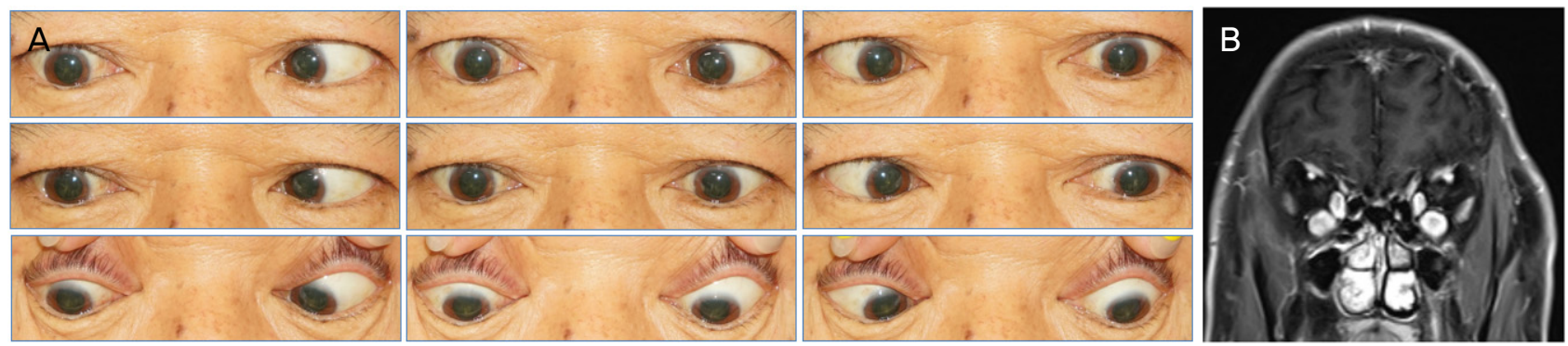

Figure 2. Patient 9 with nine diagnostic position at the initial presentation. (A) Patient demonstrated esotropia and up gaze limitation of the both eyes. (B) Magnetic resonance imaging of the brain showed enlargement of the inferior rectus muscle and medial rectus muscle in the both eyes. 
환자의 증상은 일중 변화를 동반하지 않았다. 6년 전 거미 막밑출혈로 치료받았으며, 좋은 회복을 보였다. 그 외 다른 전신질환의 과거력은 없었고, 사시와 복시의 과거력도 없 었으나 흡연자였다. 이전에 교정시력은 양안 20/20이었다. 동공반응검사에서 상대구심동공운동장애는 없었다. 눈꺼풀 의 이상 소견은 없었다. 안구운동검사에서 우안의 $30 \mathrm{PD}$ 내 사시와 $40 \mathrm{PD}$ 하사시, 좌안의 $30 \mathrm{PD}$ 하사시가 있으며, 양안 의 상측 운동제한을 보였다(Fig. 2A). 뇌 MRI에서 양안 안 쪽곧은근(medial rectus muscle)과 아래곧은근의 비대를 확 인하였다(Fig. 2B). 갑상선기능검사에서 TSH는 $0.01 \mathrm{mIU} / \mathrm{L}$, free T4는 $17.45 \mathrm{~mol} / \mathrm{L}, \mathrm{T} 3$ 는 $1.66 \mathrm{nmol} / \mathrm{L}$ 이었다. TRAb는 $3.08 \mathrm{U} / \mathrm{L}$ 이고, TPOAb와 anti-thyroglobulin antibodies는 음 성이었다. 갑상선초음파에서 비균질한(heterogeneous), 낮 은에코결(hypoechoic texture)의 경미한 갑상선종을 확인하 였고, 정상 도플러혈류를 보였다. Tc-99 m 갑상선스캔에서 양측 엽의 비대와 약간 불규칙적인 섭취를 보였다. 환자는 무증상 갑상선기능항진 진단을 받았으며, 저용량 methimazole $(2.5-5.0 \mathrm{mg})$ 치료를 시작하였다. 치료 3개월 뒤 갑상 선호르몬 수치는 호전을 보였으나, 사시는 변화가 없었다. 사시수술로 양안의 아래곧은근 $5 \mathrm{~mm}$ 후전술과 우안의 안 쪽곧은근 $6 \mathrm{~mm}$ 후전술을 시행하였고, 환자는 수술 후 복시 의 호전을 보였다.

\section{고 찰}

이 연구에서 후천사시와 복시를 첫 증상으로 갑상선눈병 증과 갑상선기능항진을 진단받은 경우는 남성에서 더 많았 다. 하사시가 가장 흔한 형태의 사시였고, 남성 흡연자에서 사시의 치료로 수술이 필요한 경우가 많았다.

후천사시와 복시 환자에서 원인 병변이 외안근, 신경근 이음부, 또는 뇌신경 중 어느 부위인지 알아내는 것은 중요 하다. ${ }^{1}$ 왜냐하면, 복시를 유발하는 원인은 다양하고, 정확한 진단이 적절한 치료 방향을 결정하는 데 중요하기 때문이 다. 양성 원인에 의한 경우는 자연 호전될 수도 있으나, 갑 상선기능항진이 동반된 갑상선눈병증의 경우처럼 내과적 치료가 필요한 경우도 있다.

갑상선눈병증은 자가면역질환으로 갑상선기능항진과 관 련 있는 경우가 많다. ${ }^{2-4}$ 눈꺼풀올림근(levator palpebrae superioris)이 영향을 받는 경우가 많으며, 따라서 눈꺼풀뒤당 김이 갑상선눈병증의 가장 흔한 임상 소견이다. 성인에서 눈꺼풀뒤당김 또는 눈꺼풀내림지체(lid-lag)를 동반한 후천 사시는 갑상성눈병증에 의한 것임을 예측할 수 있다. ${ }^{7}$ 이 연구에 포함된 대부분의 환자들은 눈꺼풀 이상 소견이나 안구돌출을 동반하였다.
이전에 갑상선기능이상을 진단받은 환자에서 후천사시 와 복시의 발생은 갑상선눈병증을 원인으로 쉽게 예측할 수 있다. 그러나 후천사시와 복시가 눈 증상으로 처음 나타 나서 갑상선눈병증과 갑상선기능이상을 진단받을 수 있으 며, 이러한 경우 안과의사가 환자의 갑상선기능이상을 처 음으로 진단하는 것일 수 있다. ${ }^{5}$ 이전의 갑상선눈병증에 의 한 후천사시와 복시에 대한 연구들은 주로 사시 발생 이전 에 갑상선눈병증 또는 갑상선기능이상을 진단받았던 환자 들을 대상으로 하였다. ${ }^{89}$ 이에 본 연구에서는 후천사시와 복시로 처음 내원하여 갑상선눈병증과 갑상선기능항진을 진단받은 환자들의 임상양상을 알아보고, 이를 통해 복시 환자의 원인 감별을 하는 의사의 진료에 도움을 주고자 하 였다.

이 연구에서 후천사시와 복시로 갑상선눈병증과 갑상선 기능항진을 진단받은 환자는 여성보다 남성이 더 많았다. 일반적으로 갑상선기능이상과 갑상선눈병증의 성별 분포 는 남성보다 여성에서 많은 것으로 알려져 있다., ${ }^{2,4,8,10}$ 그러 나, 이 연구의 결과로 복시의 원인 감별에 있어서 성별 차 이로 갑상선눈병증과 갑상선기능항진의 가능성을 배제할 수는 없을 것이다. 남성 중 절반 정도가 경과 관찰 중 사시 수술을 시행 받았고, 이는 갑상선눈병증을 가진 남성에서 증상의 중증도가 심하다는 이전 연구의 결과와 일치한다. ${ }^{2,4}$ 그리고 남성은 심한 갑상선기능항진을 동반하지 않고도 갑 상선눈병증으로 진행할 가능성이 높았다. ${ }^{11}$ 이것의 원인은 명확하지 않지만, 흡연과의 관련성을 생각할 수 있다. 총 9명 의 남성 환자 중 6 명이, 사시수술을 시행 받은 4 명이 흡연 자였다. 이전 연구에서도 흡연은 중증 갑상선눈병증과 사 시의 수술 치료가 필요한 정도의 증상 악화와 관련을 보였 다. ${ }^{2,412}$ 따라서, 안과 의사는 후천사시와 복시가 동반된 갑 상선눈병증환자에서 흡연과 증상 악화의 관련성을 환자에 게 설명하고, 금연을 권유하는 것이 필요할 것이다.

눈운동장애의 형태에서는 하사시가 연구에 포함된 환자 들에서 가장 많았고, $4 \mathrm{PD}$ 에서 $40 \mathrm{PD}$ 까지 다양한 정도를 보 였다. 갑상선눈병증에서 사시는 외안근의 비대에 의한 눈 운동제한에 의해 발생한다. ${ }^{1,7,10}$ 아래곧은근과 안쪽곧은근 이 흔하게 영향을 받아서, 하사시와 내사시가 나타날 수 있 다. 그러나, 어떠한 외안근도 영향을 받을 수 있기 때문에 갑상선눈병증에서는 다양한 형태의 사시가 발생할 수 있 다. ${ }^{1}$ 그리고 갑상선눈병증환자에서는 자가면역질환인 눈증 증근육무력증(myasthenia gravis)이 동반될 수 있다. ${ }^{5}$ 이 연 구에서도 1 명(환자 8)이 혈액검사에서 항아세틸콜린수용체 항체 양성 소견을 보여, 약물치료를 받게 되었다. 이전 연 구에서 갑상선눈병증환자에서 눈꺼풀처짐이나 외사시의 발생은 눈중증근육무력증의 동반 발생을 고려하여야 한다 
고 했다. ${ }^{13}$ 환자 2 는 큰 각의 외사시를 보였으나, 혈액검사 에서 항아세틸콜린수용체항체가 음성이었고 눈꺼풀처짐이 없었으며, 복시 증상의 하루 변이를 동반하지 않아서 눈중 증근육무력증 가능성은 낮다고 판단하였다.

본 연구는 작은 수의 환자를 포함하는 한계가 있다. 따라 서, 흡연의 기간, 금연의 효과, 갑상선기능항진의 치료 방법 등의 다양한 요인이 질환의 경과에 미치는 영향에 대한 분 석을 시행할 수는 없었다. 이러한 다양한 요인에 따른 임상 경과의 차이를 알기 위해 국민건강영양조사와 같은 많은 수의 환자를 포함한 자료를 이용한 추가 연구를 시행할 것 이다. 그리고, 갑상선기능저하나 정상갑상선기능을 보인 갑 상선눈병증환자는 연구에서 제외하였다. 이러한 환자들은 진단이 모호할 수 있으며, 정상갑상선기능환자들은 내과적 치료의 대상도 아니기 때문이다. 그러나 갑상선눈병증환자 가 갑상선기능항진과 관련 있는 경우가 많아서, 이 연구의 결과는 후천사시와 복시 환자의 원인을 조사하고 치료 방 향을 결정하는 의사에게 도움을 줄 수 있을 것이다. ${ }^{2,3,4,8}$

\section{REFERENCES}

1) Biousse V, Newman JN. Neuro-ophthalmology illustrated, 2nd ed. New York: Theme, 2016; chap. 13.

2) Maheshwari R, Weis E. Thyroid associated orbitopathy. Indian J Ophthalmol 2012;60:87-93.

3) Bahn RS. Graves' ophthalmopathy. N Engl J Med 2010;362:726-38.
4) Lazarus JH. Epidemiology of Graves' orbitopathy (GO) and relationship with thyroid disease. Best Pract Res Clin Endocrinol Metab 2012;26:273-9.

5) Kim WJ, Moon JS, Kim MM. Exotropia and hypotropia as the initial presentation sign of thyroid eye disease in an 18-year-old man. J AAPOS 2018;22:71-3.

6) Mourits MP, Prummel MF, Wiersinga WM, Koornneef L. Clinical activity score as a guide in the management of patients with Graves' ophthalmopathy. Clin Endocrinol (Oxf) 1997;47:9-14.

7) Harrad R. Management of strabismus in thyroid eye disease. Eye (Lond) 2015;29:234-7.

8) Tanda ML, Piantanida E, Liparulo L, et al. Prevalence and natural history of Graves' orbitopathy in a large series of patients with newly diagnosed graves' hyperthyroidism seen at a single center. J Clin Endocrinol Metab 2013;98:1443-9.

9) Bartley GB, Fatourechi V, Kadrmas EF, et al. The incidence of Graves' ophthalmopathy in Olmsted County, Minnesota. Am J Ophthalmol 1995;120:511-7.

10) Bartley GB. The epidemiologic characteristics and clinical course of ophthalmopathy associated with autoimmune thyroid disease in Olmsted County, Minnesota. Trans Am Ophthalmol Soc 1994;92: 477-588.

11) Marcocci C, Bartalena L, Bogazzi F, et al. Studies on the occurrence of ophthalmopathy in Graves' disease. Acta Endocrinol (Copenh) 1989;120:473-8.

12) Rajendram R, Bunce $C$, Adams GG, et al. Smoking and strabismus surgery in patients with thyroid eye disease. Ophthalmology 2011;118:2493-7.

13) Chen CS, Lee AW, Miller NR, Lee AG. Double vision in a patient with thyroid disease: What's the big deal? Surv Ophthalmol 2007;52:434-9. 


\section{$=$ 국문초록 $=$}

\section{갑상선기능항진과 갑상선눈병증의 첫 증상으로서 후천사시와 복시}

목적: 후천사시와 복시가 갑상선눈병증과 갑상선기능항진의 첫 임상증상이었던 환자들의 임상양상을 분석하고자 한다. 대상과 방법: 2017년 1월부터 2018년 12월까지 후천사시와 복시로 내원한 환자들의 의무기록을 후향적으로 분석하였다. 이들 중 복시 의 원인감별을 위해 시행한 검사에서 갑상선눈병증과 갑상선기능항진을 진단받은 환자들이 연구에 포함되었다.

결과: 연구기간 동안 410 명의 환자가 후천사시와 복시로 안과에 의뢰되었고, 이 중 12 명이 연구에 포함되었다 $(2.9 \%, 12 / 410)$. 복시가 발생한 평균 나이는 54.7년이었다(범위, 18-78년). 이 중 9명(75\%, 9/12)이 남성이었다. 6 명의 남성이 흡연자였다. 하사시가 가장 흔한 형태의 사시였다(83.3\%, 10/12). 평균 하사시각은 17.5PD였다(범위, 4-4OPD). 한 명은 외사시와 하사시를 보였고, 1 명은 내사시와 양 안 상측 운동제한을 보였다. 경과 관찰 중 4 명의 남성이 사시수술을 시행 받았으며, 이들은 모두 흡연자였다. 한 명의 여성이 안와감압 술을 시행받았다.

결론: 후천사시와 복시로 갑상선눈병증과 갑상선기능항진을 진단받은 경우는 남성에서 더 많았다. 하사시가 가장 흔한 형태의 사시였 으며, 흡연하는 남성에서 여성보다 더 심한 임상경과로 진행할 가능성이 많았다.

〈대한안과학회지 2020;61(3):288-293〉

정승민 / Seung Min Chung 영남대학교 의과대학 내과학교실 Department of Internal Medicine, Yeungnam University College of Medicine

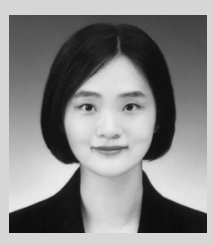

